\title{
THOMAS SPENGER COBBOLD AND BRITISH PARASITOLOGY
}

\author{
by \\ W. D. FOSTER
}

T. S. СоввоцD was one of the most eminent parasitologists of the nineteenth century, being during his lifetime certainly the chief British authority on the subject. Indeed, wrote a contemporary reviewer, 'of British helminthology it is not too much to say he is the practical founder'. ${ }^{1}$ Although he is not remembered for any particular discovery of importance he did most valuable work, original, confirmatory, advisory and educational in the field of helminthology.

Cobbold died at the age of fifty-eight. His short life was not enlivened by any dramatic events but seems to have been passed happily in intensive work over a wide field of natural history. He was particularly devoted to parasitology at a time when the subject was almost entirely neglected in Great Britain.

Cobbold was born in 1828 in Ipswich, Suffolk, of a family long established in that county. Both his father and paternal grandmother were people of some distinction. His grandmother, Elizabeth, was descended from Edmond Waller the poet and was herself a minor poetess and novelist. She is said to have been of indefatigable industry, a characteristic passed on to her son and grandson. She was also artistic and with a taste for natural history. She assisted Sir W. Smith with his Flora Anglica and W. Sowerby named a shell after her, Nucula Cobboldiae. She, however, died before the birth of the subject of this article. ${ }^{2}$

Cobbold's father Richard was a typical well-to-do country clergyman of the times, often rode with the hounds and was a keen sportsman with rod and gun. He was in addition a successful author, writing many novels. His best known work was The history of Margaret Catchpole, a Suffolk girl, being based on the life of the celebrated adventuress who had been saved from hanging by his father's influence. He was a man of keen intelligence, lively humour, some artistic ability and large conversational powers. ${ }^{3}$

T. S. Cobbold was first sent to school to the Rev. H. Burrows at Yarmouth and thence to the Charterhouse. Having determined on medicine as a career he was, at the age of sixteen, apprenticed to J. G. Crosse, surgeon of Norwich. In this he was indeed fortunate. Crosse was a Fellow of the Royal Society and besides being an able surgical practitioner was keenly interested in the scientific basis of his profession. He possessed premises licensed under the Anatomy Act for the dissection of the human body and had accumulated a fine museum of pathological specimens. During his career he had a series of forty apprentices including George Humphry, later the first professor of surgery at Cambridge. ${ }^{4}$

During three years spent under Crosse, Cobbold's bent towards natural history was fostered and canalized particularly into the study of comparative anatomy and he became a skilful dissector. In 1847, on the advice of Crosse, 


\section{W. D. Foster}

he proceeded to Edinburgh University armed with an introduction to James Syme, the Professor of Surgery, with whose family he became intimate. Professionally, however, he was less interested in clinical work than in the scientific basis of medicine and during his second year he assisted J. H. Bennett who was very active in pathological research and who had recently been appointed Professor of the Institutes of Medicine. Bennett had been largely responsible for the introduction of the microscope as a tool in clinical medicine and it was doubtless from him that Cobbold received his earliest instruction in the use of the instrument.

Cobbold's interest in comparative anatomy and his skill in dissection led to a more lasting connexion with John Goodsir, the Professor of Anatomy, and he was entrusted with the dissection of the specimens used by Goodsir to illustrate his lectures. In 185 I he took his M.D. degree, gaining a gold medal, and went to Paris for a short period of postgraduate study. As was later said of him, 'he had never the manner or habits of a physician' and he never took any other medical qualification or became a member of the Royal College of Physicians.

Not being entirely dependent upon his profession for his daily bread, he resolved not to practise medicine but to devote himself to a career in biology and on his return to Edinburgh was appointed curator of the anatomical museum.

In 1852 he married a Miss Amys of Richinghall in Suffolk, which union was in due time blessed with daughters and a son who took up medicine as a career.

For a few months Cobbold came under the influence of that magnetic personality Edward Forbes, who at the age of thirty-nine in 1854 had been appointed Professor of Natural History in the university. Forbes lived to enjoy his chair only six months but his brilliant lectures and weekly geological expeditions to the surrounding countryside fired Cobbold with an interest in geology. He acquired a respectable knowledge of the subject and a large collection of specimens which later in life enabled him to fill the Swiney chair of geology at the British Museum with distinction. ${ }^{6}$

Cobbold's main work in Goodsir's department lay in the field of comparative anatomy and several communications on the topic were made to the learned societies of Edinburgh. His interests were, however, still wide, and, for example, in 1853 he wrote a short but not highly original paper on the histological changes in the ovary of an orchid following pollination.?

His interest in parasitology almost certainly arose as a result of observing the numerous parasites in the various animals which he dissected. The literature on parasites in English was scanty and he soon started to scan the continental journals for new facts on what was becoming his favourite pursuit. In 1854 he made his first parasitological discovery whilst dissecting a giraffe. In the bile ducts he found numerous specimens of a species of Fasciola which were, however, much larger than the well known Fasciola hepatica of sheep. He named this new species Fasciola giganta and must have been very proud of this discovery for ten years later he used a coloured drawing of this parasite as the frontispiece to his great book on the Entozoa. ${ }^{8}$ 


\section{Thomas Spencer Cobbold and British Parasitology}

He was not, however, content merely to make casual observations in helminthology and was probably the first person in this country to resort to the experimental approach in the attempt to establish the relationship between the various stages in the life history of parasites. The great merit of having introduced feeding experiments for this purpose belongs to $\mathrm{F}$. Kuchenmeister, who in $185^{\mathrm{I}}$ hit upon the plan of administering the cystic stages of parasitic worms to animals and after a suitable interval dissecting them to see what type of tapeworm had developed in the animal's intestine. In this way he succeeded in proving that the cysticercus pisiformis of the rabbit was but the cystic stage of Taenia serrata in the dog and that cysticercus fasciolaris of the mouse was similarly related to Taenia crassicollis in the cat. ${ }^{9} \mathrm{~A}$ few years later the same worker showed by the rather cold-blooded experiment of feeding cysticercus cellulosae 'in blood puddings from which the fat was removed and replaced by cysticerci' to a criminal before execution, that they were the cystic stage of Taenia solium. ${ }^{10}$

Cobbold at once appreciated the value of this technique and in 1856 fully confirmed Kuchenmeister's results with respect to cysticercus pisiformis, the life cycle of which at that date was still a matter of controversy. ${ }^{11}$ For the rest of his career Cobbold freely resorted to animal experiment as far as expense would allow and obtained a grant of money from the British Association for the Advancement of Science for this purpose. ${ }^{12}$

In 1857 he decided to seek fame, if not fortune, in London, the attraction of Edinburgh being much lessened by the premature death of Edward Forbes, to whom he had become deeply attached. His first appointment in London was that of lecturer in botany at St. Mary's Hospital and in 186I he obtained a similar post at the Middlesex Hospital where he also lectured on zoology and comparative anatomy. Cobbold never obtained an official post of the first rank in London although in 1872 he became professor of botany and helminthology at the Royal Veterinary College. He became a member of many learned societies, both British and foreign, and was at one time President of the Quekett Microscopical Club and of the Physiological Society of Edinburgh.

Cobbold was a good lecturer, clear but dogmatic, and considered lectures to be a most valuable method of instruction. In addition to lecturing to academic audiences he was in great demand as a popularizer of the rapidly advancing biological sciences. In 1860 , in a lecture to a lay audience at the Royal Institution on 'the scope, tendency and educational value of the natural history sciences' he expounded enthusiastically on the excellent training in observation and reasoning which such studies afforded, observing is it not a privilege to commune with those whose minds are imbued with a love of nature, as she attires herself in the ever-varying attitudes of organized existence'.13

In order to devote himself to his scientific work Cobbold refused to undertake any form of medical practice. He obtained permission to dissect the animals dying in the Zoological Society's garden and in the four years $1857-60$ examined 122 animals in a search for parasites. 14 This source, together with contributions from farmers, the market and sporting friends, soon provided him with a great practical experience of parasitology. Meanwhile his practical experience was 


\section{W. D. Foster}

supplemented by extensive reading. He ransacked the libraries of the Royal College of Surgeons, the Linnean, Zoological and Royal Medico-Chirurgical Societies for parasitological literature in English, being surprised at the extensive though scattered contributions. With the aid of continental correspondents, who included some of the most eminent parasitologists such as C. M. Diesing and $\mathbf{R}$. Leuckart, he was able to build up a tolerably complete collection of the foreign literature. ${ }^{15}$

By nature Cobbold was sociable, a pleasing after dinner singer and of considerable charm, which talents no doubt helped him to build up a wide circle of friends and acquaintances, and it was not long before he was known as the chief British authority on helminthology. ${ }^{16}$

Although eschewing clinical work Cobbold was fully alive to and interested in the public health aspects of parasitology. In 1862 he published a list of all the entozoa known to infest man with a good description of each of the thirty species. ${ }^{17}$ In scientific and semi-popular journals he continued to emphasize the dangers of exposure to infection by helminths and point out the precautions by which they could be avoided. A British military expedition to Abyssinia prompted a lecture on the parasites to be expected in that region, in which he laid down that 'a very few simple precautions, you perceive, may prevent a multitude of evils ... let them be taken; and good, which may be unseen by the ignorant, will result'. He added also a personal note in pessimistic mood. 'For my own part, I may add that the prospect of this contingent result is the only sure reward which many years of toil bring to an almost singlehanded English investigator in this department of experimental and practical zoology.'18

However recognition, if not more mundane rewards, he did receive. In the summer of 1864 he was elected to the Fellowship of the Royal Society and with the publication in the autumn of the same year of his fine book Entozoa, an introduction to the studv of helminthology his reputation as a parasitologist equal to the greatest on the Continent, and the first in Great Britain and her growing tropical empire, was established. The book was received enthusiastically; 'a noble contribution to the literature of the subject', 'a credit to our national literature',19 'a fresh starting place', 'enables the student of helminthology to comprehend the precise position which that science now occupies'20 were some of the comments of reviewers. All were also unanimous on the elegant standard of production: 'emphatically what our friends across the channel would call an édition de luxe. Printed on the finest paper and adorned with numerous and very beautiful illustrations, it is perhaps the handsomest work on a medical subject with which we are acquainted.' 21 One minor criticism there was and that was of the meagreness of the clinical descriptions, which was excused on the grounds that the author was not a practical physician.

The scope of the work was briefly as follows. The first part consisted of I 40 pages devoted to 'systematic helminthology or a general account of the habits, structure, development, affinities, distribution and classification of the entozoa and their allies'.22 This was followed by the main part of the work on 'special helminthology; or an outline of the anatomical peculiarities, origin, 


\section{Thomas Spencer Cobbold and British Parasitology}

mode of development and propagation of the entozoa infesting man; with a particular account of the injurious effects they produce, including a brief notice of the remedies employed in medical practice. ${ }^{23}$ The third part consisted of a short account of some parasites not belonging to the order of helminths such as fly larvae which invade the skin, the account of which is partly based upon reports and specimens received from J. Kirk, the doctor accompanying David Livingstone in his African expeditions. In this section he also dealt with certain frauds which seem to have been not uncommonly practised by some patients, such as putting minute freshwater worms into their urine. Cobbold recalled seeing such a patient whilst an apprentice to Mr. Crosse. ${ }^{24}$ The book was rounded off with a fine bibliography, extending to sixty pages, of all the more important works on internal parasites that had appeared in English during the previous fifty years. His aim was to do for British and American authors what Davaine in his Traité des entozoaires, et des maladies vermineuses had done for continental writers, and Cobbold considered that taken together their works 'present as complete a resumé of entozoological literature as anyone could reasonably desire or hope to obtain' ${ }^{25}$

A perusal of the text reveals much of the way Cobbold acquired his knowledge as well as its great extent, his grasp of the literature, his correspondence and exchange of specimens with some of the most eminent parasitologists, particularly Leuckart, and the prosecution of practical study both by the dissection of every animal that came his way as well as feeding experiments and even chemical analyses of the body fluids of parasites. In I869 he issued a supplementary volume giving an account of recent work, a supplementary English bibliography, a list of authorities quoted running to over six hundred authors, and a general index of the whole work. ${ }^{26}$

The success of his book encouraged Cobbold to commence practice as a physician specializing in parasitic diseases and for ten years, beginning in 1865 , he practised in Wimpole Street and later in Harley Street. What financial success accrued we do not know, but many interesting patients and pathological material from all over the world were referred to him. As he wrote, 'through the kindness of correspondents and contributors of specimens from abroad, I am constantly put in possession of novel facts in helminthology' ${ }^{27} \mathrm{He}$ was thus able sometimes to co-ordinate work done in widely separated parts of the globe, add a contribution of his own and publish it for the benefit of the world at large. It should be noted that he was scrupulous in assigning credit where it was due. The most important example of this kind of activity was in connexion with the elucidation of the part played by filariae in human pathology and the life cycle of these parasites.

On 7 March 1878 at a meeting of the Linnean society Cobbold presented on P. Manson's behalf the latter's remarkable discovery of the development of embryo filariae in the body of a mosquito. ${ }^{28} \mathrm{He}$ preceded this paper with another giving as accurate an account as he was able of the historical development of knowledge of this parasite and the part it plays in human pathology. The parasite which we now call Wuchereria bancrofti is widespread in the 
tropical and subtropical parts of the world. The adult worms live in the lymph nodes and lymph vessels of man, the female giving birth to living embryos which migrate into the blood stream. The next stage in their development takes place in the body of a mosquito and when fully developed the embryos regain access to the human body when the mosquito bites. The adult worms give rise to a low grade, chronic inflammatory process which, since they are situated within the lymphatics, may lead to lymphatic obstructions with oedematous swelling distally known as elephantiasis. Lymphatic obstructions sometimes lead to rupture of lymphatic vessels in the walls of the bladder or pelvis of the kidney when the milky lymph is passed mixed with urine giving the characteristic appearance of chyluria.

The stages in the development of our understanding of this disease were, according to Cobbold, as follows:

On 4 August 1866 O. Wucherer, whilst examining the urine of a patient with chyluria in the Misericordia Hospital, Bahia, saw embryo filariae. Subsequently he found several similar cases and published an account of them in the Bahia medical gazette in 1868 . Similar observations were made independently by several workers, notably T. R. Lewis in Galcutta in March 1870 . In July of the same year Cobbold himself saw these same embryos in the urine of a little girl suffering from bilharzia infection which was causing haematuria. The next important advance came in July 1872 when T. R. Lewis found nematode larvae in the blood of an apparently healthy Indian and three months later on examining the blood of one of his old chyluria patients found the same larvae to be present. He named the worm Filaria sanguinis hominis, although, as Cobbold pointed out, he could not be sure that the larvae were indeed filarial.

In $1876 \mathrm{~J}$. Bancroft of Brisbane observed these larvae in the blood and sent some specimens to his old teacher, Dr. Roberts of Manchester, who forwarded them to Cobbold who recognized them as larvae identical with those described by Lewis and previously seen by himself. He suggested to Bancroft that he searched for the parent worm. This Bancroft was the first to find in a lymphatic abscess in the arm on 21 December 1876 and he communicated his observation to Cobbold in the following April.

Meanwhile T. R. Lewis had been searching for the adult parasite and found it in August 1877 . His paper announcing this discovery arrived at the Lancet office a few days before Cobbold's account of Bancroft's discovery.

P. Manson had been interested in the elephantiasis problem since 1874 but, as he wrote, 'I live in an out of the world place (Amoy, China) away from libraries and out of the run of what is going on, so I do not know very well the value of my work, or if it has been done before or better'. Manson had been in the habit of communicating his observations to Cobbold, who arranged the publication of such parts as he considered of interest. It was, acting in this capacity, that he announced Manson's discovery of the larvae in the body of the mosquito. ${ }^{29}$

The final step in the parasite's life history, the entry of the mature larvae into man's body, was not discovered until twenty years later. Manson held the view 


\section{Thomas Spencer Cobbold and British Parasitology}

that the larvae escaped into water on the death of the mosquito and were subsequently swallowed by their human host. It was not until Ross had shown that a mosquito not only removes the sexual forms of malaria parasites from the human body but also reinjects the mature sporozoites that a similar mechanism was demonstrated for filaria.

Cobbold continued active in his parasitological work almost until his death. In 1872 he had been appointed Professor of Botany and Helminthology at the Royal Veterinary College, where he was the first to introduce the study of parasitology into the curriculum, and he continued to fulfil the duties of the post until incapacitated by his final illness.

In 1879 he published a new text-book, Parasites; a treatise on the entozoa of man and animals including some account of the ectozoa. This was not a new edition of his earlier book but an entirely new work with a far wider design in view. He dealt in the first half of the book with the parasites of man, omitting minute anatomical descriptions and most clinical details yet dealing fully with those aspects of the natural history of parasites important in their epidemiology. The second half of the book was devoted to a description of the various types of parasites which had been recorded from all classes of animals from mammals to invertebrates. This part of the book, he hoped, would enable naturalists to identify any parasites they came upon in the course of their dissections and was in some measure an act of self defence, for hundreds of correspondents were constantly seeking his ever forthcoming help in the identification of their 'finds'. This work was intended to 'place a reasonable limit upon the number of future applicants' ${ }^{30}$ As with his earlier work, the bibliography was one of the most important features, 'bringing to a focus the records of, and principal references to, a widely scattered, intricate and voluminous literature'. ${ }^{31}$

This important book was by no means the last of his literary productions. Subsequent works included a short manual of human parasites published in $\mathrm{I} 882$ in which all known species of metazoa, endo- and ecto-parasites were described, and although the parasitic protozoa and bacteria were not dealt with their importance was fully recognized. ${ }^{32}$ In the same year he also published a monograph on the parasites of elephants.

In 1885 Cobbold's health began to fail and following a fainting attack after speaking at a meeting at the Middlesex Hospital he was found to have aortic disease and cardiac hypertrophy. During the winter, which was particularly cold, he became subject to angina pectoris and severe breathlessness. Knowing his days to be numbered, he dearly wished to live long enough to enjoy another spring and summer which meant so much to him as a naturalist. But it was not to be and when he died at his London residence on 20 March I 886 it was said of him that it was 'not too much to affirm that his peculiar place in the profession can hardly be filled up'. ${ }^{33}$ 
I. Edin. med. F., I880, xxv, 449 .

2. СоввоцD, E. D.N.B.

3. CоввоLd, R. D.N.B.

4. Crosse, J. G. D.N.B.

5. Lancet, $1886,1,616$.

6. LEYLAND. Contemporary medical men and their professional work. Leicester, I888, 1, 30.

7. Quart. F. micro. Sci., 1853 , 1.

8. Edin. new. philo. Mag., 1855, I, 262.

9. KUCH E M E IST E R, F. On animal and vegetable parasites of the human body. Trans. E. Lankester. London, 1857, 26.

10. Ibid., p. II5.

11. Сов BOLD, T. S. Entozoa: an introduction to the study of helminthology. London, 1864, 209.

12. LEYLAND. Contemporary medical men and their professional work. Leicester, 1888, I, 30.

13. СоввоLD, T. The scope, tendency and educational value of the Natural history sciences. London, 1860.

14. Proc. zool. Soc. Lond., 1861.

15. СоввоLD, T. S. Entozoa: an introduction to the study of helminthology. London, 1864, viii.

16. Brit. med. F., 1886, I, 620.

17. Proc. zool. Soc. Lond., 1862.

18. Lancet, $1867, \mathrm{Ir}, 763$.

19. Ibid., 1864, II, 353 .

20. Med. Times. Gaz., 1864, II, 474 .

21. Edin. med. F., 1865, 1, 929.

22. Сов во D, T. S. Entozoa: an introduction to the study of helminthology. London, 1864, I.

23. Ibid., p. 142.

24. Ibid., p. $4^{12}$.

25. Ibid., p. 421 .

26. Сов вогD, T. S. Entozoa, being a supplement to the introduction to the study of helminthology. London, 1869 .

27. Brit. med. F., 1876, 1, 780 .

28. F. Linn. soc. (zool.), 1878, xrv.

29. Ibid., p. 356 .

30. СоввоцD, T. S. Parasites: a treatise on the entozoa of man and animals. London, 1879, vi.

31. Ibid., p. v.

32. Сов воLD, T. S. Human parasites: a manual of reference to all the known species of entozoa and ectozoa. London, $1882,85$.

33. Lancet, $1886,1,616$. 